\title{
DEVELOPMENT OF IOT BASED SMART INVERTER FOR ENERGY METERING AND CONTROL
}

\author{
Buhari U. Umar*, ORCID: 0000-0001-6971-1917, \\ Bello K. Nuhu, ORCID: 0000-0003-0130-2468, \\ Olaoluwa. M. Alao, ORCID: 0000-0002-1727-3246
}

\begin{abstract}
Department of Computer Engineering, Federal University of Technology, Minna, PMB 65, Minna, Niger state Nigeria, ${ }^{*}$ Corresponding author: Buhari U. Umar, buhariumar@futminna.edu.ng
\end{abstract}

Received: 09. 22. 2021

Accepted: 11. 12. 2021

\begin{abstract}
Insufficient power generation has facilitated the search for alternative power generation, as the world is gradually making the transition to renewable green energy sources as a replacement for fossil fuels and other conventional power generation methods that causes environmental pollution. One of these methods is the use of solar energy for electricity generation through the use of the photovoltaic solar inverter which harnesses the power from the sun to generate electricity. The inability of electricity distributors to provide enough and sustainable power supply for homes and businesses, coupled with the need to live a smart life has made humans sort for an easier control method of electricity generation and usage. Hence, this research presents a smart voice and mobile application control modular inverter integrated with a smart metered energy distribution system, which equally distributes power amongst the users for effective and smart energy usage. A test of applied load on the inverter as compared to normal electricity usage deduced an $8 \%$ error rate giving a $92 \%$ accuracy for the inverter. The mobile app was tested for both online and offline usage and a $67 \%$ accuracy was deduced as the overall accuracy of the software. This gives an inference that the system can be fully operated by a user in the luxury of their comfort. For smart meter monitoring and energy allocation, $93.33 \%$ and $96.8 \%$ accuracy and precision were achieved respectively. This research makes the usage of green energy more efficient with its feature which allows for equal distribution of energy. The system also helps prevent energy theft or misuse by providing only the proper user with alerts and administrative control.
\end{abstract}

Keywords: Smart Energy Meter, Voice Automation, Smart Switching, IoT.

Rezumat. Generarea insuficientă a energiei a facilitat căutarea unei generații alternative, deoarece lumea realizează treptat tranziția la surse regenerabile de energie verde ca înlocuitor pentru combustibilii fosili și alte metode convenționale de generare a energiei care provoacă poluarea mediului. Una dintre aceste metode este utilizarea energiei solare pentru generarea de energie electrică prin utilizarea invertorului solar fotovoltaic care valorifică puterea soarelui. Incapacitatea distribuitorilor de energie electrică de a furniza o sursă de energie suficientă și durabilă pentru case și afaceri, împreună cu nevoia de a trăi o viață 
inteligentă, i-au făcut pe oameni să caute o metodă de control mai ușoară a producerii și utilizării energiei electrice. Această cercetare examinează un invertor modular pentru controlul aplicațiilor mobile și voce inteligentă integrată cu un sistem inteligent de distribuție a energiei, care distribuie în mod egal puterea între utilizatori pentru o utilizare eficientă și inteligentă a energiei. Un test al sarcinii aplicate pe invertor în comparație cu utilizarea normală a energiei electrice a dedus o rată de eroare de $8 \%$, oferind o precizie de $92 \%$ pentru invertor. Aplicația mobilă a fost testată atât pentru utilizare online, cât și offline și a fost dedusă o precizie de $67 \%$ ca acuratețe generală a software-ului. Acest lucru conduce la concluzia că sistemul poate fi operat pe deplin de către un utilizator în luxul confortului său. Pentru monitorizarea contoarelor inteligente și alocarea energiei, au fost atinse 93,33\% și, respectiv, 96,8\% acuratețe și precizie. Această cercetare face ca utilizarea energiei verzi să fie mai eficientă datorită caracteristicii sale care permite o distribuție egală a energiei. Sistemul ajută, de asemenea, la prevenirea furtului sau a utilizării greșite a energiei, oferind alerte și control administrativ doar utilizatorului corespunzător.

Cuvinte cheie: Contor inteligent de energie, Automatizare voce, Comutare inteligentă, IoT.

\section{Introduction}

On account of the modern revolution, electricity is the major component that fuels a nation's economy. Businesses, homes and the public authorities are vigorously subjected to constant electricity for all-day activities. Electricity is a form of energy that can be produced either by heat (sun), water (hydro), wind (windmill) or from wasted materials to power devices that creates heat or light. Methods of electricity generation have distinctive advantages over each other and there has never been the best method to generate electricity. Researchers are constantly searching for an alternative, better and safer means of electricity generation [1]. The methods of electricity generation mostly used include hydro and fossil fuels which have resulted in a continuous increase rate of flooding and environmental contamination from gasoline generators exhaust causing environmental hazards [2]. Asides from contaminating the air and polluting the environment, these methods have been identified as the main factor contributing to the increase in greenhouse gas effect in the atmosphere. Also, less reliance and the disappointing nature of electricity generation boards especially in developing countries has resulted in a huge loss of revenue for businesses and organizations [3]. Therefore, it is imperative to zero in on the idea of utilizing sustainable energy effectively thereby generating and storing electricity from secondary sources to reduce the tension and congestion on power grids.

One of the methods of generating zero-emission, and better reliable electricity is through Solar inverters. With rising innovative advances, solar inverters have become one of the most reliable options for the generation of electricity, storage and distribution of electricity which is more even brilliant than the normal power grid. This involves the trapping of the sun using Photo Voltaic (PV) cells and storing the electric charge produced in a battery [4]. Direct current electricity generated by photovoltaic systems is converted to alternating current using converters, which are harmonic sources. [5]. Solar photovoltaic (PV) energy has become a substantial and important renewable energy source in the global energy market, and it is growing. This expansion is owing to continuous improvements in efficiency, power, and reliability, among other factors [6]. The optimum use of this technology could cover a huge piece of the energy interest in many developing countries. Utilizing its different viewpoints is extremely needed especially in a country like Nigeria where there is no constant 
electricity and the slow/gradual upgrade to existing grids have not been sufficient to cater for the increasing needs of electricity users.

Inverters assume a vital role in any solar-based energy generation framework and it is frequently defined as devices that converts Direct Current (DC) to Alternating Current (AC) at required frequency and voltage using energy dissipated from the sun. Integration of renewable energy sources has sparked widespread attention in recent years as a means of reducing fossil fuel emissions, alleviating load demand congestion, and lowering electricity prices in the power generation market. This is due to the ease with which inverters, which are commonly utilized in residential applications, can be installed and used. Solar inverters should have a digital design, robust software facilities, and two-way communication capability to make the system intelligent; a system of robust, reliable, and proficient siliconbased hardware that can be controlled by an adaptable software environment control structure capable of remote controlling for faster and better control. This control interface can be developed by employing loT technology to achieve high reliability with reduced human stress through adequate control using wireless technologies like Bluetooth, Wi-Fi or RFID. Hence, this research presents a smart voice and mobile application control modular inverter integrated with a smart metered energy distribution system, which equally distributes power amongst the users. This system provides accurate measurement of power consumption and displays it to the consumer via a mobile android application for remote monitoring. Also, the system helps to eliminate power wastage due to negligence, inadequate control, and multiple access to the inverter by unauthorized persons.

\section{Review of Related Work}

A Smart Energy Meter (SEM) is an electronic device that includes an energy meter chip, data connection protocols, security features, and a data display interface for tracking electric energy usage [7]. Smart meters are distinguished from traditional energy meter systems by their ability to communicate. A smart meter may track active power consumption as well as other information such as voltage and current phasors, reactive power, maximum power demand, frequency, and power factor in real-time. With the progress of technology and the use of loT, smart meters must be developed to utilize device and communication technologies to achieve user satisfaction [4]. Such devices can be enhanced with capabilities such as multilevel indicators [7, 8], advanced and artificial intelligence-based control policies [9, 10], userfriendly interface [11, 12], energy management system [13], IoT capabilities [1] and other additional functions [14]. This section presents the recent advances in inverter development. Renewable energy sources are now being employed to address energy demands as a result of increased energy demand and pollution caused by rapidly depleted fossil fuels [15]. Solar energy, which uses PV (Photo Voltaic) modules to generate power, is one of the most widely used renewable energy sources. By charging batteries during the day and then utilizing the stored energy in the battery when the sun isn't shining, solar energy can be used to generate and store power. Smart inverters are inverters that convert Direct Current (DC) to Alternating Current (AC) [16], are possibly charged by solar energy, and can track the sun as designed in [8]. Smart inverters, on the other hand, are inverters that communicate in both directions with the user and other stakeholders in the system [17] also, show that such a system exists [4] presented a smart inverter that communicates with the user in a two-way manner, telling the user of the inverter as well as the run time of the loads that the user chooses to operate. Loads are also regulated electronically to enhance human comfort. The study focuses on 
improving power supply dependability for high-demand loads, particularly critical loads. [2] shown how to make a smart home with a Raspberry Pi and a smart inverter. This study presented a bi-level (Supervisory-Local) PV-based microgrid system for low-power residential applications. At the supervisory level, a long-term control scheme is assigned to determine the setpoints for local controllers. [18] also includes a variety of instruments, electronic technology, and software. The present PV system monitoring methods have some limitations, such as limited automation and slow response times. These problems can be prevented with a good remote environment information monitoring and control system. This system should include automatic diagnosis procedures in the PV station. In addition, a study published in [19] proposed an "loT-based smart energy meter" for efficient energy usage. It's crucial for the electrical system's development of a smart grid. As a result, the smart grid's power usage monitoring and control is a primary focus. One of the challenges with the energy meter is the lack of full-duplex transmission. A smart energy meter based on the Internet of Things is presented as a solution to this problem. The smart energy meter manages and computes energy use using an ESP 8266 12E Wi-Fi module and sends the data to the cloud, where the consumer or customer can examine the results.

A smart inverter integrated with Raspberry Pi for smart home was proposed by [20]. The inverter can be controlled using a mobile phone so far there is an internet connection on the user's phone. The system is adapted with an Infrared (IR) sensor which monitors the state of the appliances connected to the system. Once the status of any of the systems is triggered from ON to OFF or otherwise, the state new state is stored in a database and displayed on a pre-developed website. Users can also turn on and off the appliances at their convenience over the Web-Application. A similar system is developed by [21]. The basic difference between these systems is that the latter uses LCD to monitor current, voltage and power consumption and can be controlled using a GSM module. The implementation of the smart meter can be integrated into a power grid as discussed by [22]. This requires stepping up or stepping down the power supplied to the power grid by the inverter such that if the grid voltage is $230 \mathrm{~V}$ and the inverter supply $300 \mathrm{~V}$, the inverter voltage is stepped down to $230 \mathrm{~V}$ and vice versa. This is done through a PWM inverter. This type of inverters can be controlled using an intelligent micro inverter control scheme that continuously contains Volt-Var control, Low Voltage Ride Through (LVRT) and system frequency response [23].

In terms of speech, mobile application control, and smart energy monitoring and allocation, the proposed method in this study differs from the reviewed relevant studies. When compared to the research in [20 - 22], the system's method of control is a web application and voice control via Bluetooth capable of controlling the modular inverter remotely through wireless fidelity communication technology (Wi-Fi), which makes the use of green energy more efficient with its feature that allows for equal energy distribution. The technology also helps to avoid energy theft or misuse by restricting notifications and administrative control to only the appropriate users.

\section{Design Methodology}

This section presents the design, development and working principles of the developed smart modular solar Inverter system. The system comprises two parts: software and hardware. The voice control unit and mobile application control mechanism (a touch control interface for smartphones) are used to control the modular inverter, while the hardware is made up of numerous units that make up the modular inverter system. The 
technique is divided into three sections: solar inverter development, metering, and energy allocation; voice module control unit creation, and mobile application for the modular inverter. The aim of this research is to develop a smart energy metering and switching modular inverter which is controlled by the voice of a user and also through the mobile application software. The system is a solar inverter where energy from the sun is harvested using a Photovoltaic Solar panel and boosted using a buck-boost converter. The harnessed energy is then stored in a battery through the charge controller as shown in Figure 1.

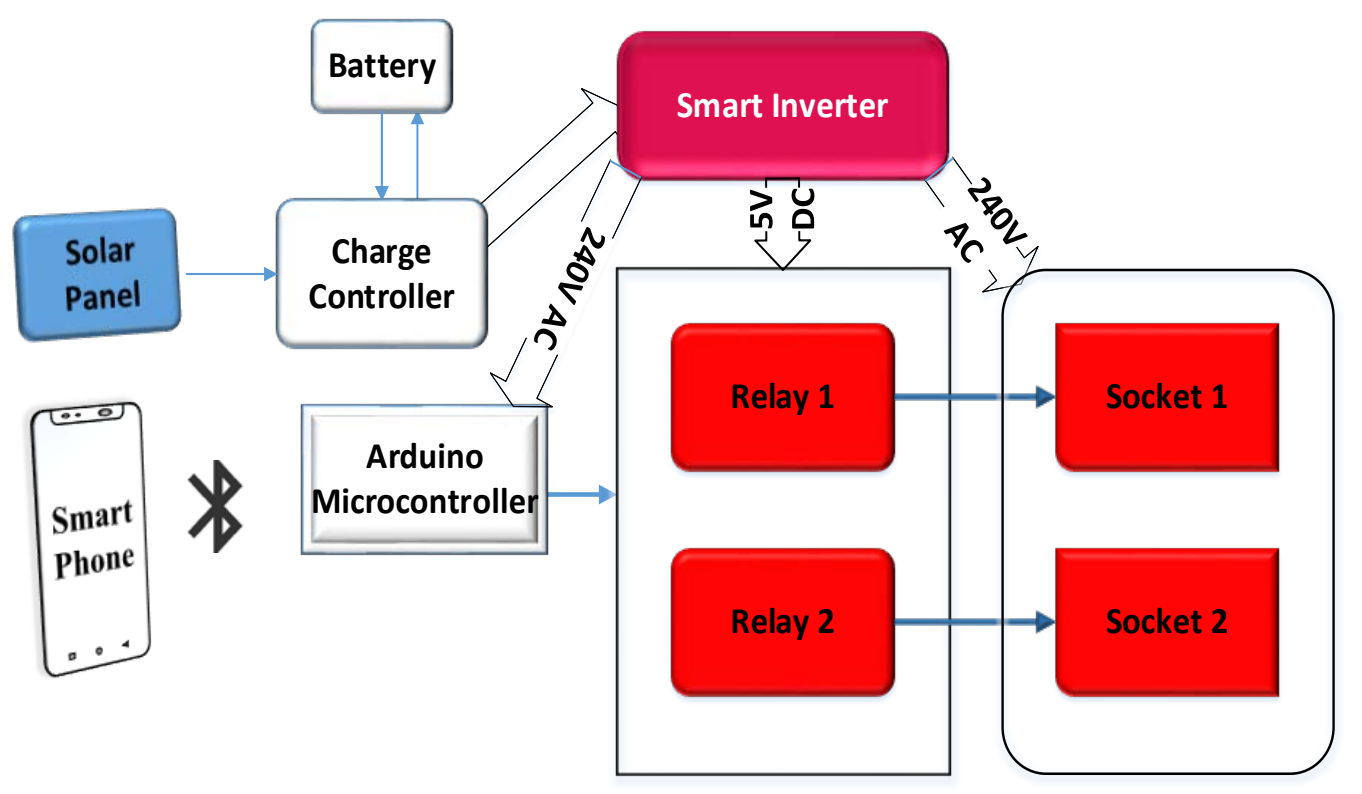

Figure 1. System Block Diagram.

The energy stored in the battery is in form of direct current (DC) and there is a need for conversion into alternating current (AC) because home appliances use alternating current (220V to $240 \mathrm{~V}$ ). This is done through the inverter. The meter controller monitors the power dissipated on the nodes to ensure that each user uses a considerable amount of power and does not affect the load usage of other nodes (users) connected to the inverter. The switching controller monitors the connected load on each of the inverter nodes, alert the user if there is an erratic current dissipated in any node and switch off that node to ensure that there is no excess current from any of the connected loads. The voice-based controller for the system allows the user to control the inverter through an loT medium (mobile app). The mobile application serves as a means of single-user authorization access and security for inverter usage. The system's controlling functions include power on/off the whole circuit, or the individual circuits connected to the system respectively. The mobile application is also the medium by which the user previews the monitoring function of the inverter. Figure 2 shows the data flow chart of the system.

\section{Development of the Switching and Metering Module}

The switching and Metering module consist majorly of a current sensor which is set to measure DC and AC for 20A. The three-output pin of the current sensor is connected to the microcontroller while the wire in and wire out pin are connected to the inverter battery to measure the current being drawn by an external device.

The module is connected in series with the relay to avoid short circuits and to accurately monitor the current going to each channel on the relay. 


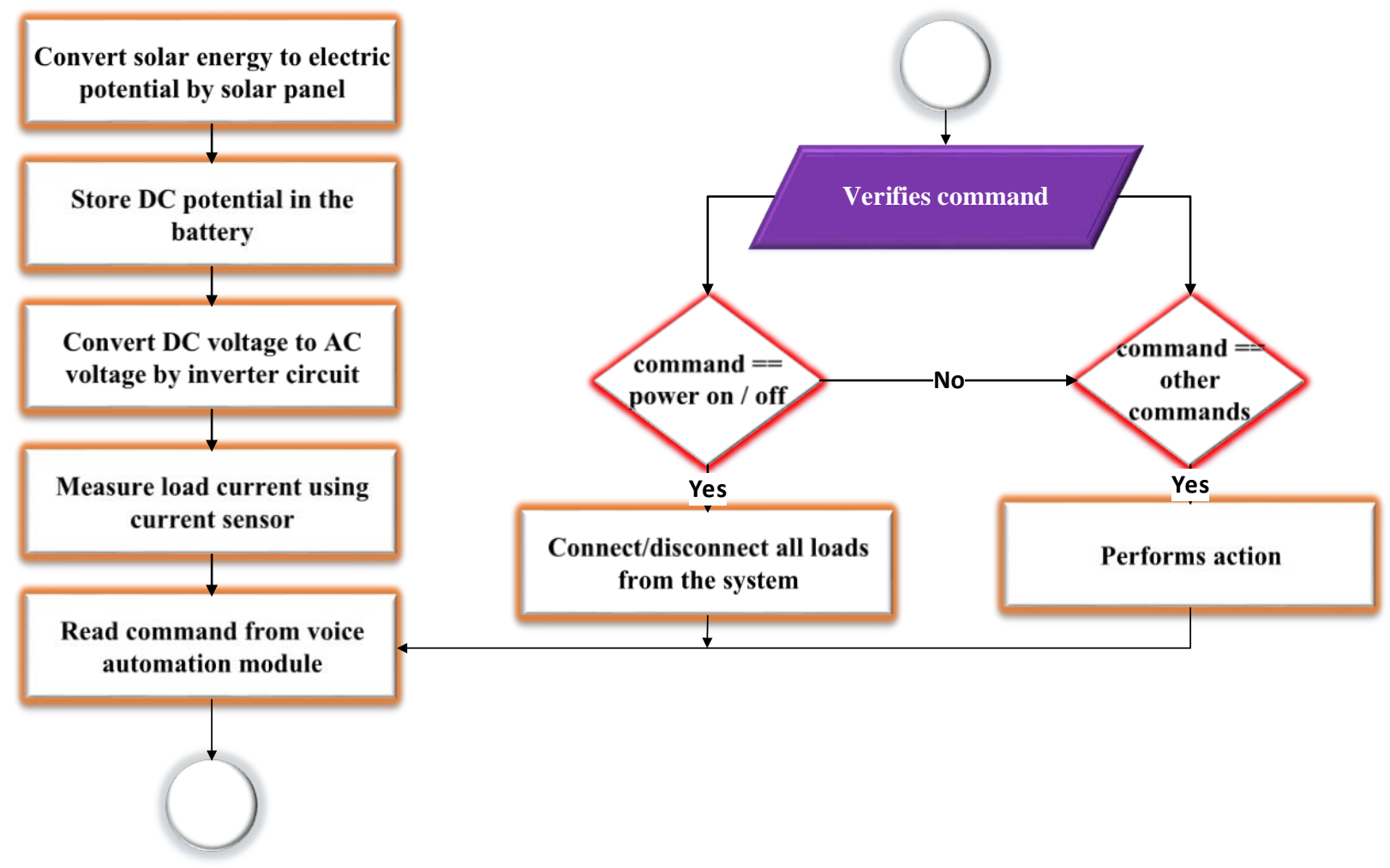

Figure 2. System Flow Chart.

The metering function is also enabled through ESP8285 ESP-M2 NodeMcu microcontroller through the current sensor which measure, distribute and regulate each power connected to the nodes of the inverter. When a node exceeds the total amount of power dedicated to it, it triggers the node off. Also, the current sensor senses loads used by each socket on the inverter. When the $20 \mathrm{~A}$ threshold is reached, the sensor automatically cut off the supply to that node and alerts the user through the mobile application. As shown in Figure 1, the system comprises a Solar panel; Charge controller; Inverter; Voltage sensor; Current sensor; ESP8285 ESP-M2 NodeMcu Wi-Fi development board; Liquid crystal display (LCD); Relay switch and Loads.

\section{PV Solar Panel}

The $12 \mathrm{~V}$ monocrystalline solar panel is placed at an angle of $45^{\circ}$ to the sun. This angle is chosen so that the reflection of the sun can directly hit the PN junction on the solar panel. Presumably, the output load is in form of DC, it can be connected to load directly to the panel but there is a need for conversion to AC if the application involved is an AC load. The solar cell is represented in Figure 3 by a single diode circuit. 12 volts / 150 watts is effective in the study. When exposed to the open Sun, a solar panel may produce a peak of 12 volts at 12500 $\mathrm{mA}$. The overall load applied to the solar panel will determine its rating. Four 15-watt energysaving bulbs, a 100-watt projector, six 200-watt laptop computers, a 60-watt standing fan, a 100-watt television, a 50-watt Go-TV decoder, and twelve 7-watt phones are among the selected loads. In watts, total load $=(15 \times 4)+100+(200 \times 6)+60+100+50+(7 \times 12)=$ $1654 \mathrm{~W}=1.654 \mathrm{KW}$. We have chosen to add some ability to deal with extra random little force utilization gadgets making the determined absolute burden of 1.7KW. Force in KVA = power in watt/power factor $=$ power in KW/0.8. Force in KVA $=1.7 / 0.8=2.125 \mathrm{KVA}$. The solar panel power rating required is $2.125 \mathrm{KVA}$ (Kilovolt-Amperes). 


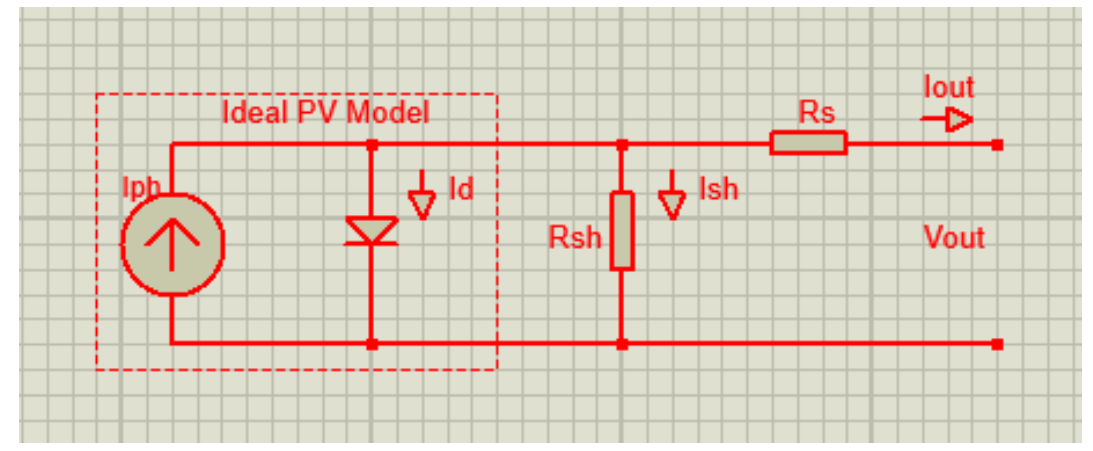

Figure 3. Equivalent circuit of the Solar Cell.

The output current of the circuit is calculated as shown in equations 1 to 4 .

$$
\begin{gathered}
I_{\text {out }}=I_{p h}-I_{\text {sat }}\left(e^{\left(q . V_{\text {out }}+R_{s} \cdot I_{\text {out }}\right)}-1\right)-\left(\frac{V_{\text {out }}+R_{s} \cdot I_{\text {out }}}{R_{p}}\right) \\
I_{p h}=\left[I_{s c}+K_{1} \cdot\left(T-T_{r}\right)\right] \frac{G}{G_{n}} \\
I_{\text {sat }}=I_{r s} \cdot\left(\frac{T}{T_{r}}\right)^{3} \cdot \exp \left\{\frac{q \cdot E_{\text {gap }}}{K \cdot A}\left(\frac{1}{T_{r}}-\frac{1}{T}\right)\right\} \\
I_{r s}=\frac{I_{s c}}{\exp \left(\frac{q \cdot V_{o c}}{N_{\text {s.A. A. . }}}\right)-1}
\end{gathered}
$$

In equations 1 to $4, I_{s a t}$ is the reverse saturation current, $I_{p h}$ is the photocurrent source, A is the ideality factor, $\mathrm{k}$ represents Boltzmann constant $\left(1,3806503.10^{-23} \mathrm{j} /{ }^{\circ} \mathrm{k}\right), \mathrm{T}$ is the solar cell surface temperature, $R_{s}$ is the series resistance, $R_{p}$ is parallel resistance, $I_{\text {sat }}$ is short circuit current, $k_{i}$ is a measure of open-circuit voltage, $T_{r}$ is reference temperature of the solar cell, $I_{r s}$ is reverse saturation current at a reference temperature, $E_{\text {gap }}$ is the energy bandgap $q$ is electron charge $\left(160217646.10^{-23 \circ} \mathrm{C}\right), V_{\text {out }}$ is open-circuit voltage and $N_{s}$ is the number of cells connected in series. Equation 5 describes the Maximum Power $\left(P_{\max }\right)$ and the Parallel Resistance $\left(R_{p}\right)$ of the solar cell is expressed in equation 6 .

$$
P_{\max }=V_{m p} . I_{\text {out }}
$$

Given that,

$$
\begin{gathered}
I_{\text {out }}=I_{\text {ph }}-I_{\text {sat }}\left(e^{\left(q \cdot\left(V_{\text {out }}+R_{s} \cdot I_{\text {out }}\right)\right.}-1\right)-\left(\frac{V_{\text {out }}+R_{s} \cdot I_{\text {out }}}{R_{p}}\right) \\
P_{\max }=V_{m p} \cdot\left\{I_{\text {ph }}-I_{\text {sat }}\left(e^{\left(q \cdot\left(V_{\text {out }}+R_{s} \cdot I_{\text {out }}\right)\right.}-1\right)-\left(\frac{V_{\text {out }}+R_{s} \cdot I_{\text {out }}}{R_{p}}\right)\right\} \\
R_{p}=\frac{V_{m p}+R_{s} \cdot I_{m p}}{\left\{V_{m p} \cdot I_{p h}-V_{m p} \cdot I_{\text {sat }} \cdot\left(\exp \left(\frac{q \cdot\left(V_{m p}+R_{s} \cdot I_{m p}\right)}{N_{s} A \cdot k \cdot t}\right)-1\right)-P_{\max }\right\}}
\end{gathered}
$$




\section{Boost Converter}

By short-circuiting and open-circuiting the MOSFET as shown in figure 4, the boost converter was utilized to convert a variable and low Direct Current (DC) source to a constant and higher DC voltage periodically. If the solar inverter's input side is a PV system, this assists to get the highest efficiency. $V_{c}$ represents the input voltage, $L$ is the impedance, $R_{L}$ is the resistance input inductance, $\mathrm{D}$ is the diode, $R_{c}$ is the output capacitor's resistance, and $\mathrm{C}$ is the output capacitor's and $V_{m}$ is the MOSFET voltage. The power dissipated is represented as $P_{0}$.

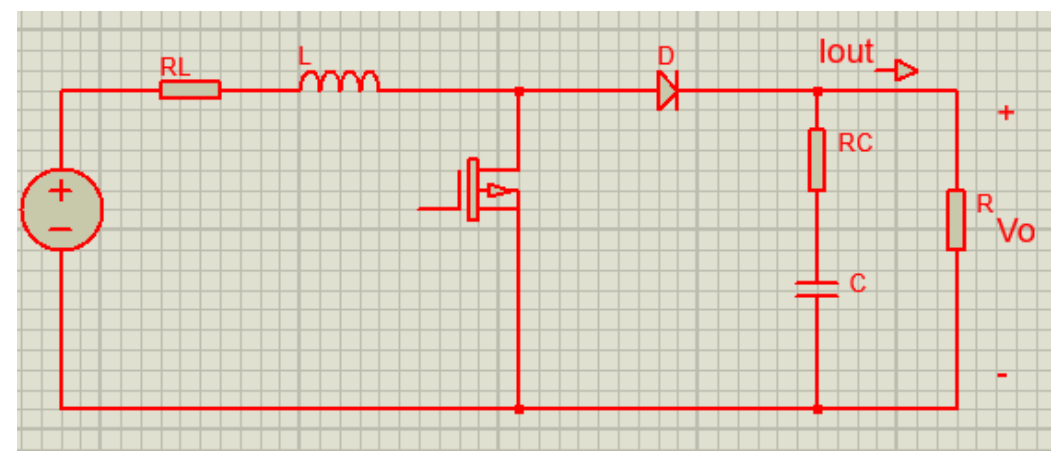

Figure 4. Schematic of A Bulk Booster.

The output voltage of the bulk booster is calculated as shown in Equations 9 to 10.

$$
V_{o}=\frac{\left(R+R_{c}\right) \cdot(1-D) \cdot R}{\Delta} \cdot V_{G}-\frac{\left(R+R_{c}\right) \cdot(1-D) \cdot D \cdot R}{\Delta} \cdot V_{M}-\frac{\left(R+R_{c}\right) \cdot(1-D)^{2} \cdot R}{\Delta} V_{c}
$$

$\Delta=\left(R_{L}+R_{M}\right) \cdot\left(R+R_{C}\right)+\left(R \cdot R_{C}+R \cdot R_{D}+R_{c} \cdot R_{D}-R \cdot R_{M}-R_{M} \cdot R_{C}\right) \cdot(1-D)+R^{2} \cdot(1-D)^{2}$

The output power when the switch is opened is calculated as shown in equation 11.

$$
P_{o}=\frac{V_{o}^{2}}{R}=\frac{V_{s}^{2}}{(1-D)^{2} R}
$$

\section{Charge Controller and Solar Battery}

In solar power systems, the charge controller is a crucial component. It is the charge administrator, especially when a battery bank is involved in the system. This manages and controls the battery's charge. It keeps the battery from being overcharged and also prevents the battery from being discharged. A lead-acid battery with a capacity rating of $12 \mathrm{v} / 100 \mathrm{AH}$ was employed in this study. The lead-acid battery belongs to the rechargeable and secondary battery categories. Despite the battery's low energy-to-volume and energy-to-weight ratios, it can deliver higher surge currents. These are the batteries that turn chemical energy into electrical energy by using lead peroxide and sponge lead. Because of the enhanced cell voltage levels and low cost, these are commonly used in substations and power systems. Equation 12 is used to calculate the charging time of a battery in ideal conditions.

$$
T_{b}=\frac{A_{p}}{I}
$$


Where $T_{b}$ is the battery charging time and $A_{p}$ is the battery ampere-hour rating while $I$ represent the current in ampere when $10 \% A_{p}+1 \% A_{p}$ for power loss.

\section{Solar Inverter}

The electricity generated by the solar panels is direct current. Alternating currents power the majority of our appliances. As a result, the direct current from the solar panel must be converted to an alternating current to power the appliances, which is where the inverter comes in. The size of the inverter should be $25-30 \%$ larger than the total Watts of the appliances. As a result, we estimate the inverter to be $30 \%$ larger than the total wattage of the appliances. $1.3 \times 1.7 \mathrm{KW}=2.21 \mathrm{KW}$ (about). In $\mathrm{KVA}$, the power rating is $1.7 / 0.8=$ 2.125KVA.

\section{Development of the Voice Control Module}

The Voice module is made up of an Android app that is integrated using Google Speech-To-Text Application Programming Interface (API). The mobile application is designed to first prompt Bluetooth connection when there is no prior Bluetooth connection on the users' phone when the application is newly launched. This is because the system uses Bluetooth for connectivity and also as a security measure because Bluetooth has a maximum connectivity distance of ten (10) meters and a single user connection at a time. Once the pairing is achieved, the user can proceed to input the command through voice automation. The speech is immediately converted into matching text format and transmitted to the microcontroller through the $\mathrm{HCO} 5$ Bluetooth Module. Figure 5 present the use-case diagram of the voice control module, while Figure 6 presents the flow chart of the voice control.

The generated text is used to control/trigger the output sockets/load that would be connected to the inverter output. If the command received through the Bluetooth matches a correct pattern as programmed on the microcontroller, the appropriate circuit is powered on or off.

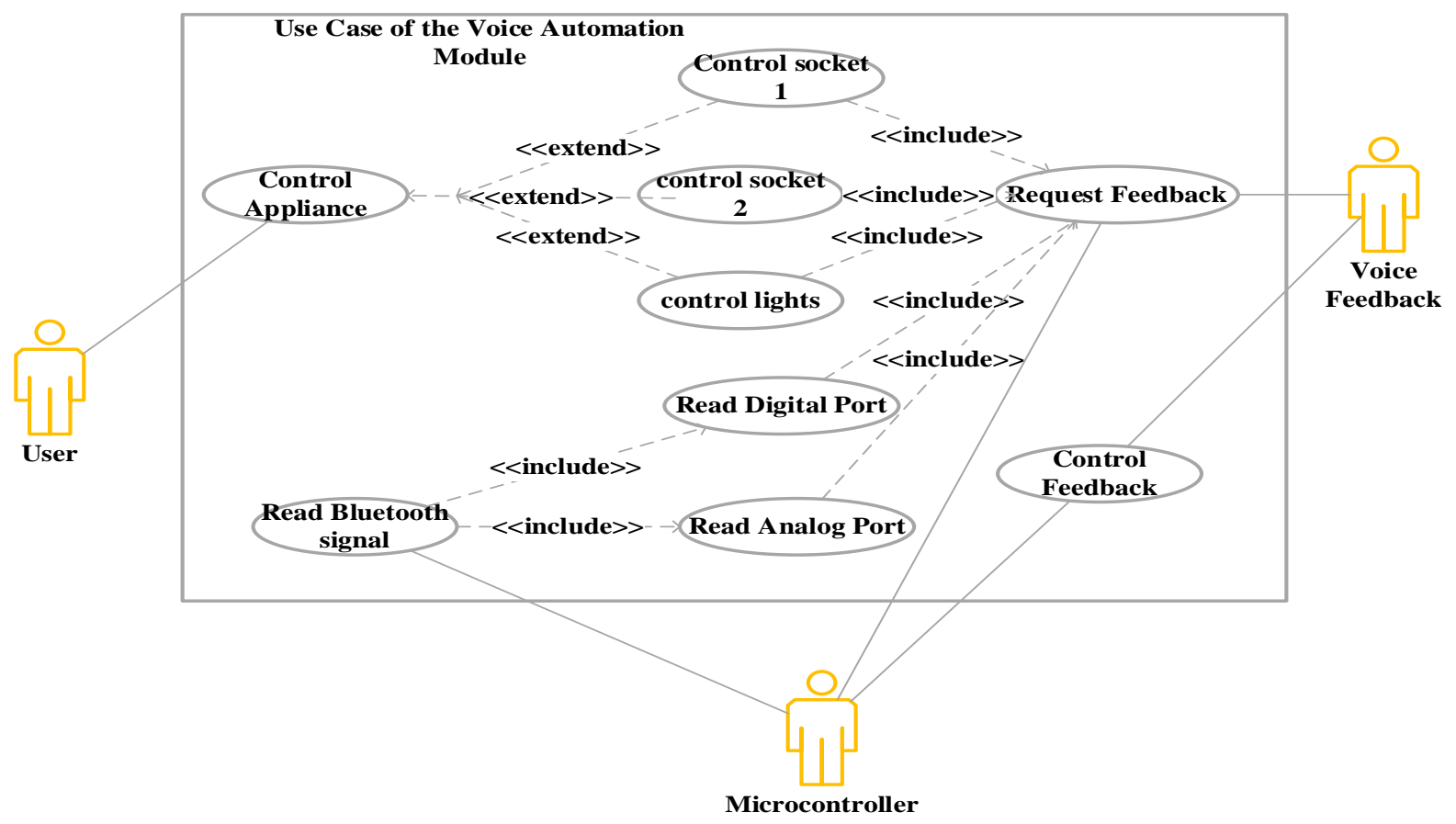

Figure 5. Use Case Diagram for the Voice Control Module. 
The mobile app is also used to monitor the load from the outlets of the inverter. It is developed with prompting and switching functionality that alerts the user when there is erratic load(s) on a socket terminal and advises the user to switch the load to another socket terminal of the inverter.

\section{Development of the Mobile Application Control Module}

This section presents smart inverter control using the mobile application. The system smart socket of the system is controlled using an loT medium (mobile application). This mobile app serves as a means of single-user authorization access and security for inverter usage. The system's controlling functions include power on/off the whole circuit, or the individual circuits connected to the system respectively. The block diagram of this developed module is shown in Figure 7.
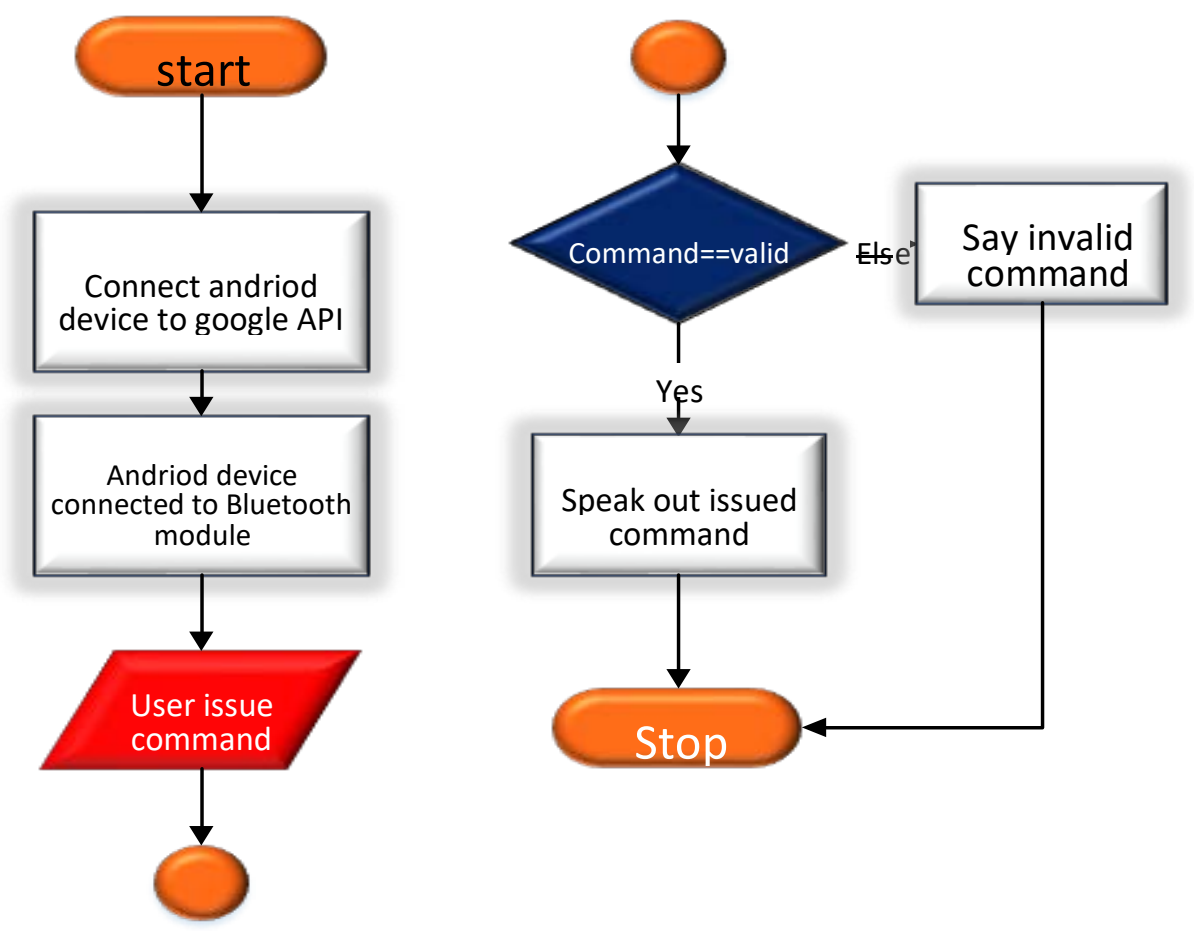

Figure 6. Flow Chart of the Voice Control.

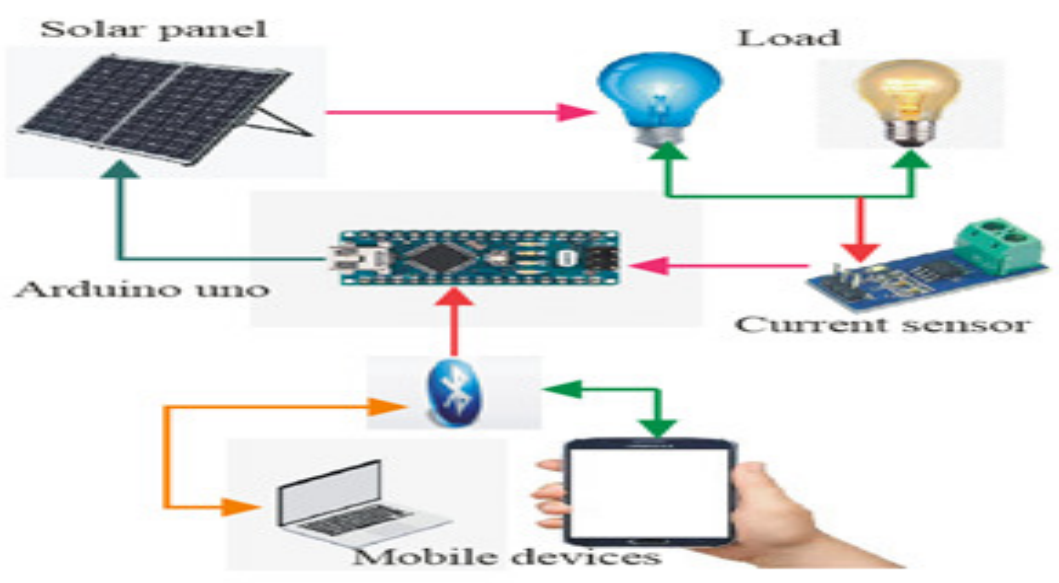

Figure 7. System Application Control Model. 


\section{Performance Evaluation}

The accuracy, response time, and precision of the proposed system were used to assess its performance. The time it takes for the voice input to produce an output, as well as the time it takes for the mobile app to respond to a command from the Google API. The precision rate is based on how closely the system repeats the values.

\section{Accuracy}

The accuracy of a system's calculated and measured values refers to how near they are to the actual value of the quantity being measured. Equation 13 is used to calculate the system's accuracy.

$$
E=\frac{T L V-S M V}{T L V} \times 100 \%
$$

Where $E$ denotes the percentage error, TLV denotes the tested load value, and SMV is the system measured value. Equation 14 was utilized as a metric to evaluate the similarity between the inputted signal and the actions carried out on the inverter as outputted by the user to determine the correctness of the mobile application module.

Accuracy,

$$
\sigma=\frac{N_{c}}{T_{i}}
$$

\section{Precision}

Precision is how close the readings are when repeated several times. It will be carried out in the system to see how precise the system reacts to the mounted voltage and power consumption in the inverter. This is shown in equation 15.

$$
\text { Precision }=\frac{\text { Measured Value }- \text { Actual Value }}{\text { Actual Value }} \times 100
$$

\section{Response Time}

The system response time is done to observe the time it takes for the connection to be established between the system Bluetooth module and the mobile application. It takes note of the time it takes to respond to the external load and its maximum input. As the time it takes to send command from the controller to the peripheral devices in charge of disconnecting overall voltage and current above the threshold of the minimum voltage programmed in the microchip. To calculate the response time, it takes the system to accept input and produce the required output as prompted by the user as shown in equation 16.

$$
\text { Response time }=\frac{T_{i}}{T_{o}}
$$

Where $T_{i}$ is the amount of time it takes to process the input and $T_{o}$ is the amount of time it takes to trigger the correct output. The processing time of the Arduino and the mobile application is also factored into the response time.

\section{Results and Discussion}

The result of the created modular inverter with optimum energy allocation and smart control system is presented in this part. This comprises hardware assembly, software application development, and system performance evaluation. The results of the system's testing are tabulated, and graphs are presented for analysis. Accuracy, response time, and 
precision are the criteria employed. Accuracy was used to assess the system's ability to provide multiple correct outputs based on the number of collected inputs. The time it took the software to handle valid and incorrect commands was measured using Response Time. Precision was utilized to assess the system by looking at how close the readings were when they were repeated numerous times.

\section{Software Development for Smart Energy Distribution}

The mobile android application software (Smart Energy Distributor) was developed with MIT Application inventor development and it employs the use of firebase database for the storage and management of data such as username, password and data acquired from the inverter module. Figure 8(a) present the login page of the mobile application, while Figure 8 (b) presents the smart energy distributor page which monitors and control the system.

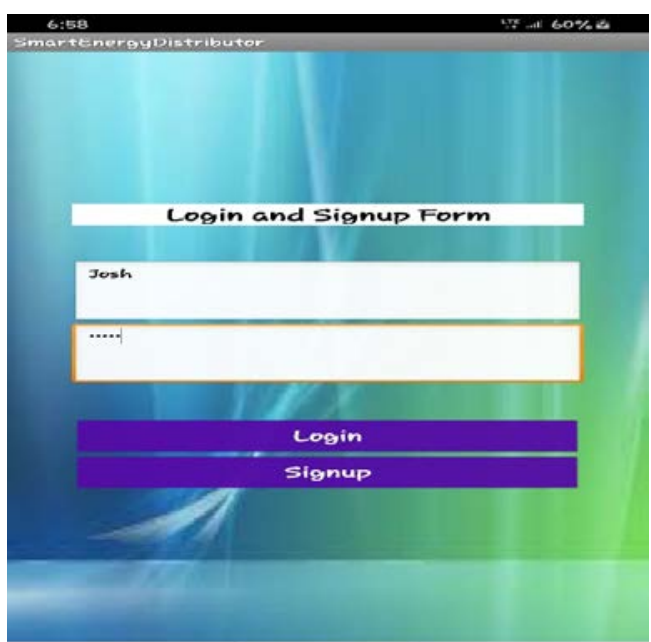

a)

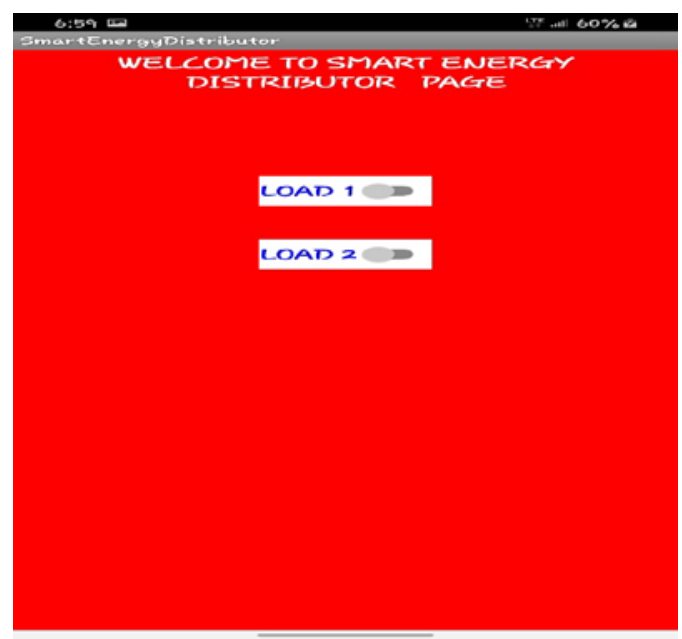

b)

Figure 8. Application Page: (a) Login Screen, and (b) Smart Energy Distributor Mobile Application.

Table 1 present the tested load ( $w)$, system measured power ( $w)$, and absolute percentage error, while figure 9 shows the accuracy of the system on the load. From figure 9 , it can be deduced that the measured values are close enough to the actual value of the tested load with a maximum calculated percentage error of 6.67 per cent. Hence the system performed optimally with $93.33 \%$ accuracy.

Table 1

Table of Accuracy Test

\section{S/N Tested Load (W) System Measured Power (W) Percentage Error (\%)}

\begin{tabular}{cccc}
\hline 1 & 15 & 14 & 6.6 \\
2 & 55 & 51.5 & 6 \\
3 & 65 & 62.9 & 3 \\
4 & 70 & 68.6 & 2 \\
5 & 85 & 84.1 & 1 \\
6 & 90 & 87.7 & 2.5 \\
7 & 100 & 100 & 0 \\
8 & 150 & 148.9 & 0.7 \\
9 & 200 & 205.4 & 2.7 \\
10 & 240 & 239.1 & 0.3 \\
\hline
\end{tabular}




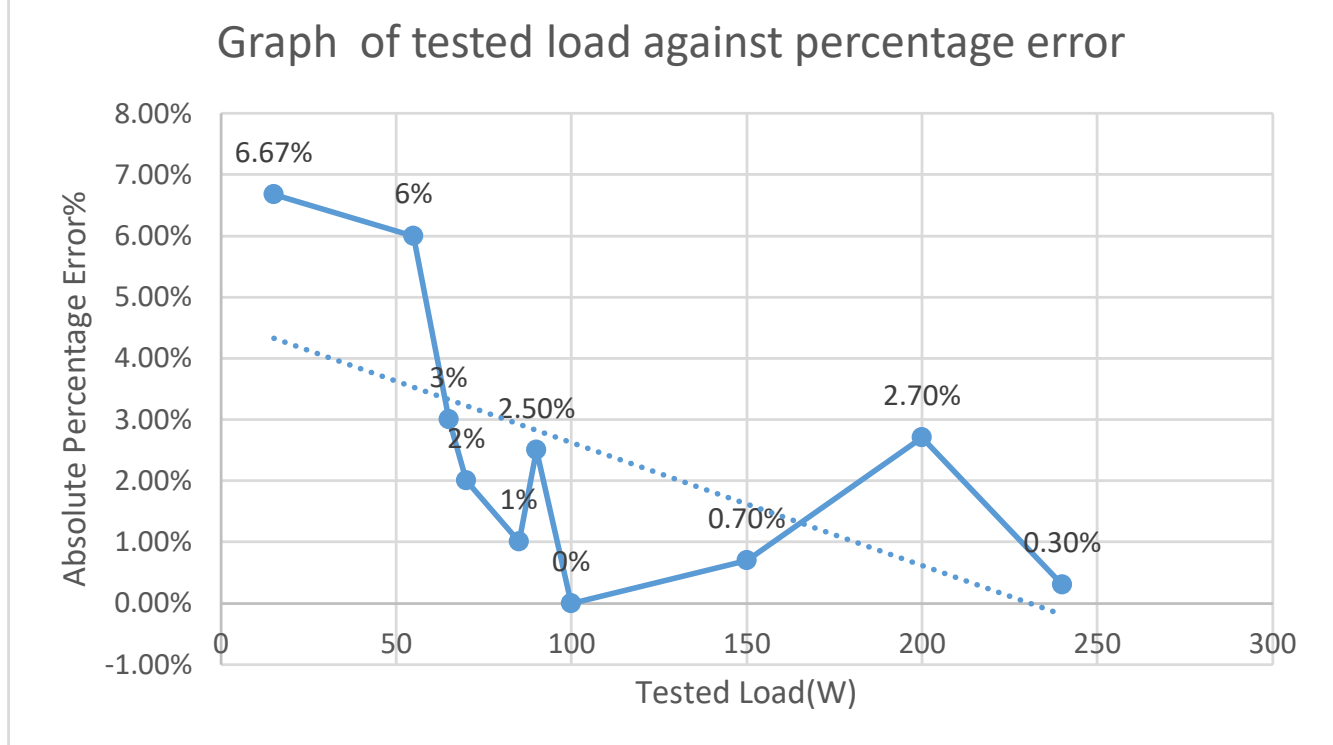

Figure 9. Graph Showing the Accuracy of the System.

When readings are repeated numerous times, precision refers to how close they are. Table 2 illustrates the findings obtained after repeating the readings up to 10 times for each load tested. As indicated in table 2, the minimum and maximum measurements were tabulated. The graph of the tested load against the minimum and maximum power is shown in Figure 10. The graph shows that the values are consistently measured within a tight range. As a result, the system's readings and measurements are accurate, with a precision of $96.8 \%$.

Table 2

\section{Precision Results}

\begin{tabular}{cccc}
\hline SN & Tested Load(W) & $\begin{array}{c}\text { Minimum Power } \\
\text { Measured (W) }\end{array}$ & $\begin{array}{c}\text { Maximum Power } \\
\text { Measured (w) }\end{array}$ \\
\hline 1 & 15 & 10 & 13.5 \\
2 & 55 & 49.1 & 59.5 \\
3 & 65 & 63.6 & 70 \\
4 & 70 & 69.4 & 73.3 \\
5 & 85 & 83.2 & 87.9 \\
6 & 90 & 87.1 & 92 \\
7 & 100 & 99.5 & 101.5 \\
8 & 150 & 147 & 154.2 \\
9 & 200 & 198.7 & 206.4 \\
10 & 240 & 230 & 241.3 \\
\hline
\end{tabular}

\section{Accuracy Results for Voice Control Unit}

The accuracy of the system is determined by plotting the number of correct outputs samples from the voice command against the total number of collected input samples. The developed software was sampled five (5) separate times with five (5) test cases for each sampling time. The numbers were chosen so that all commands can be collected using the software. Table 3 shows the data collected from the software. Figure 11 shows the total accuracy of the developed software. It can be deduced that the mobile application has a total accuracy of $63 \%$. 


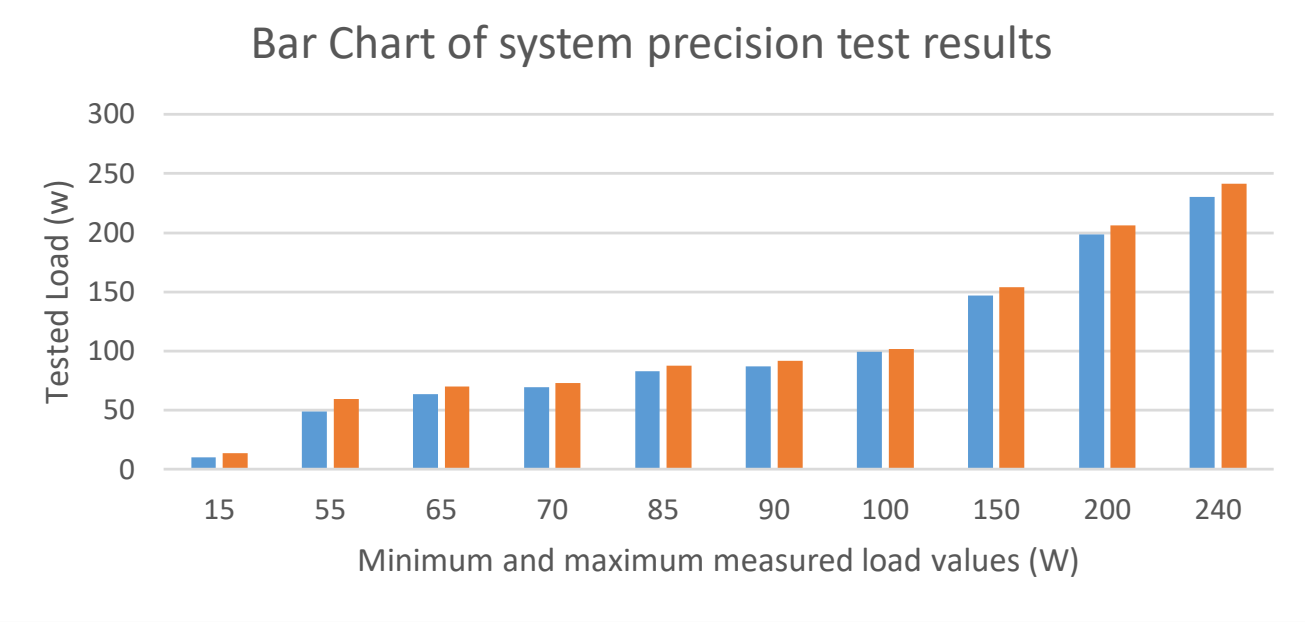

Figure 10. Bar chart showing the precision of the system.

This is due to factors such as "English language fluency of the user", "intonation of the user", and "language of the user" as the software is designed to only understand and accept commands in the English language. The software can be said to have considerable accuracy and is usable to perform the actions to which it was developed.

Table 3

Accuracy of the Software system

\begin{tabular}{ccc}
\hline Test Cases & Number of Collected input & $\begin{array}{c}\text { Number of Correct } \\
\text { Outputs }\end{array}$ \\
\hline All ON & 5 & 4 \\
All OFF & 5 & 4 \\
Load One ON & 5 & 2 \\
Load One OFF & 5 & 3 \\
Load Two ON & 5 & 5 \\
Load Two Off & 5 & 3 \\
\hline
\end{tabular}

\section{Accuracy of Software}

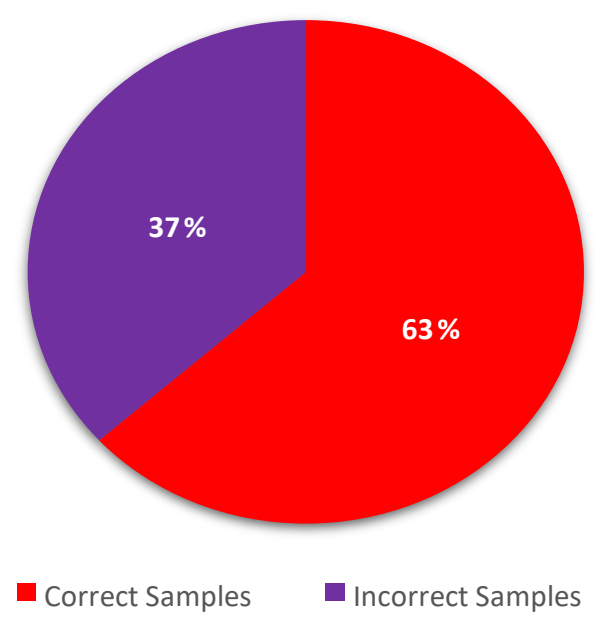

Figure 11. Total accuracy of the software. 


\section{Response Time Results}

The response time of the system is a measure of the time it takes for the system to perform the actions imputed. This was tested by imputing command via the mobile application and calculating the time the system responds to the command. The software was tested when the mobile application has no data connection (OFFLINE) and data connection (ONLINE) respectively. Result obtained is shown in table 4 and table 5 respectively.

Table 4

Response time of the software system (OFFLINE)

\begin{tabular}{ccccc}
\hline S/N & All ON (sec) & All OFF (sec) & $\begin{array}{c}\text { Other Commands } \\
\text { ON (sec) }\end{array}$ & $\begin{array}{c}\text { Other Commands } \\
\text { OFF (sec) }\end{array}$ \\
\hline 1 & 1.3 & 1.2 & 0.9 & 0.8 \\
2 & 1.2 & 1.0 & 0.8 & 0.7 \\
3 & 1.1 & 0.9 & 0.7 & 0.8 \\
4 & 1.0 & 0.7 & 0.5 & 0.9 \\
5 & 0.9 & 0.8 & 0.6 & 0.6 \\
\hline
\end{tabular}

Table 5

Response time of the software system (ONLINE)

\begin{tabular}{ccccc}
\hline S/N & All ON (sec) & All OFF (sec) & $\begin{array}{c}\text { Other Commands } \\
\text { ON (sec) }\end{array}$ & $\begin{array}{c}\text { Other Commands } \\
\text { OFF (sec) }\end{array}$ \\
\hline 1 & 1.8 & 1.5 & 1.9 & 2.0 \\
2 & 1.7 & 1.6 & 1.5 & 1.8 \\
3 & 2.0 & 2.1 & 2.4 & 2.3 \\
4 & 1.3 & 1.7 & 1.8 & 1.6 \\
5 & 1.6 & 1.3 & 1.8 & 1.6 \\
\hline
\end{tabular}

Figures 12 and 13 represent the response processing time for the software while the mobile device is ONLINE and OFFLINE, respectively. It can be determined from the results that when the device is in online mode, slight imbalances increase the processing time. The reason for this is because the service provider's mobile network fluctuates, as does the type of wireless network used by the mobile device used for testing (that is, 2G, 3G, 4G or $5 \mathrm{G}$ network).

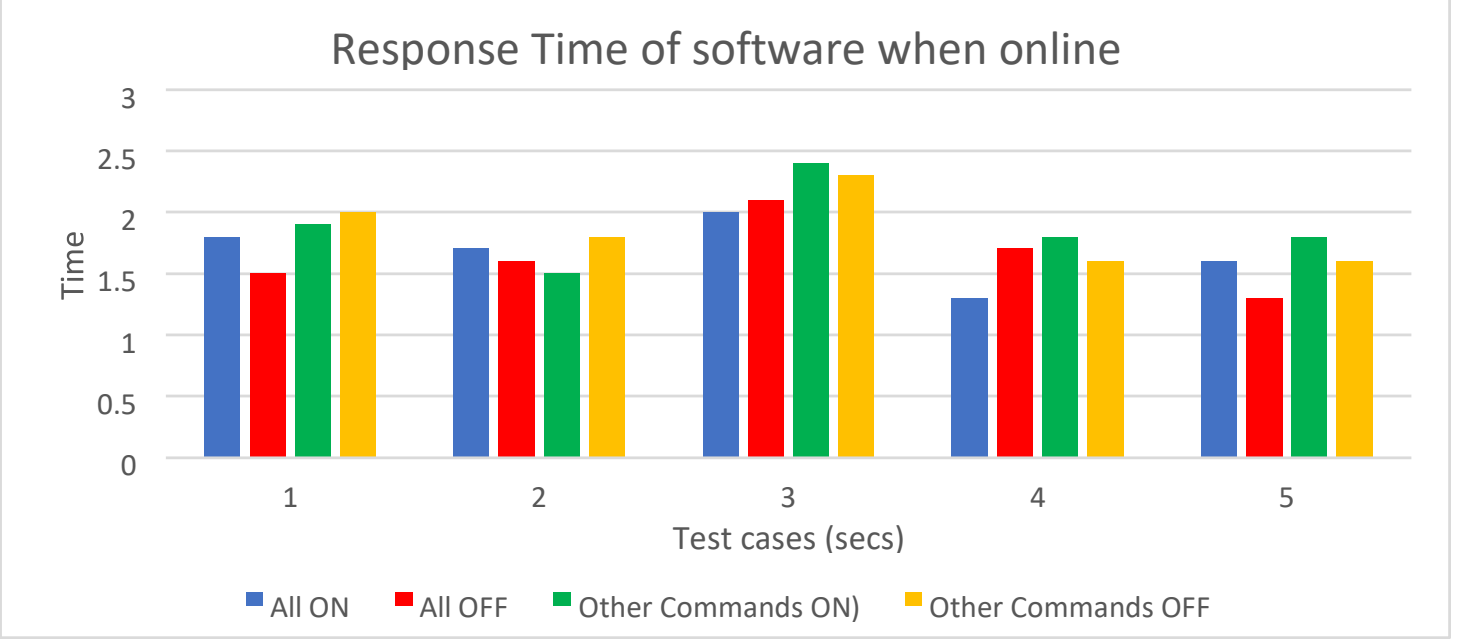

Figure 12. Response time when using the software online. 


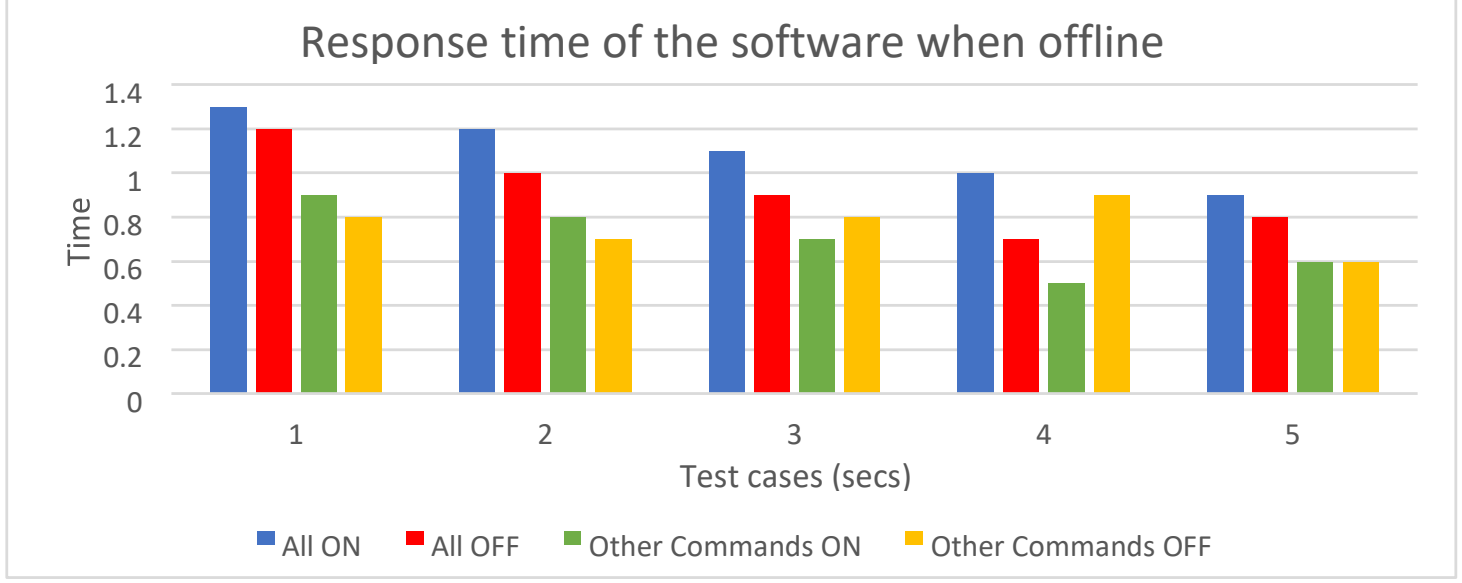

Figure 13. Response time when using the software offline.

The interface of the developed software for inverter control through an Android device is shown in Figure 14. When launched, the app automatically triggers the device Bluetooth settings of the device ON. To connect to the Bluetooth module, the button on the right side of the screen is used to navigate to the connection screen (Figure 14b). A user can scroll through the numerous already paired Bluetooth devices to click and connect to the correct Bluetooth device (HC-05). To input commands, the microphone button is pressed. The command understood from the voice command is displayed so that the user can know if the command given is correct or not. Figure 15 depicts the developed system, whereas table 6 depicts the estimated cost in Nigerian Naira for the developed system. The overall cost of the hardware and software is estimated to be N 140, 570.00 .

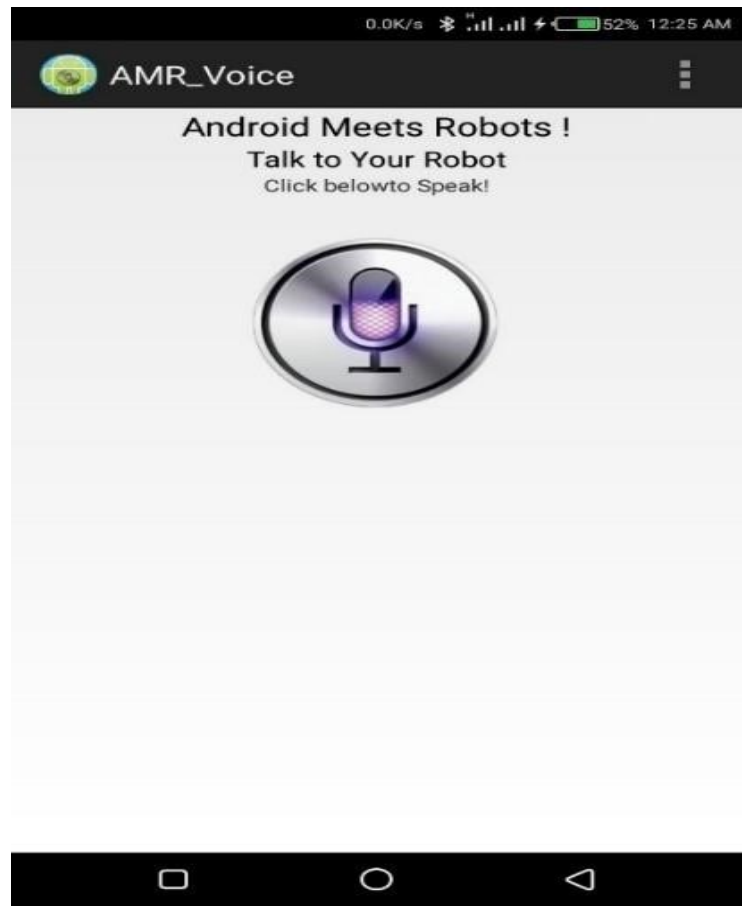

a)

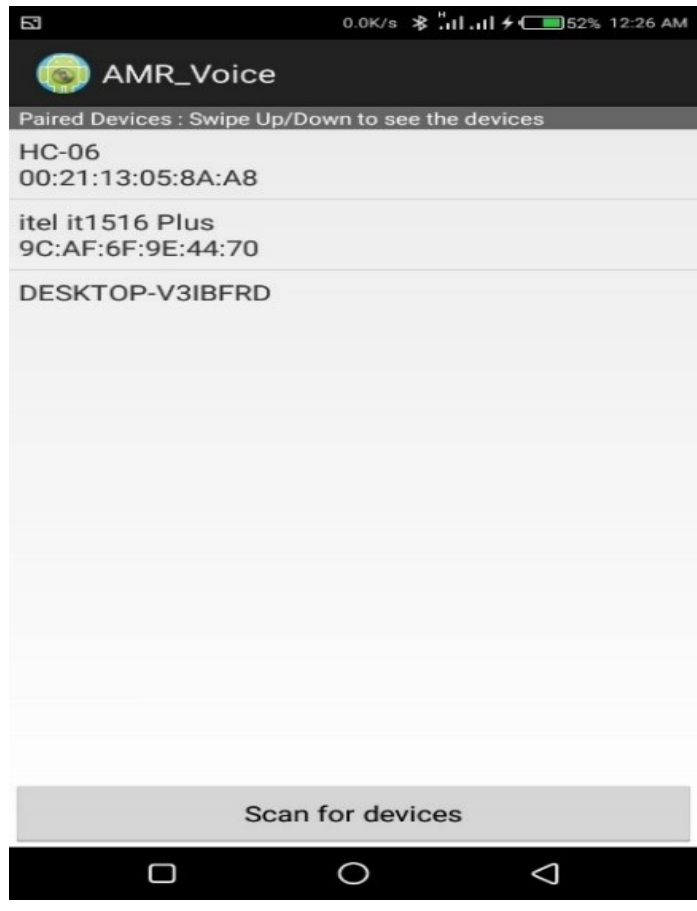

b)

Figure 14. Mobile Application (a) Home Interface, and (b) Connection Interface. 


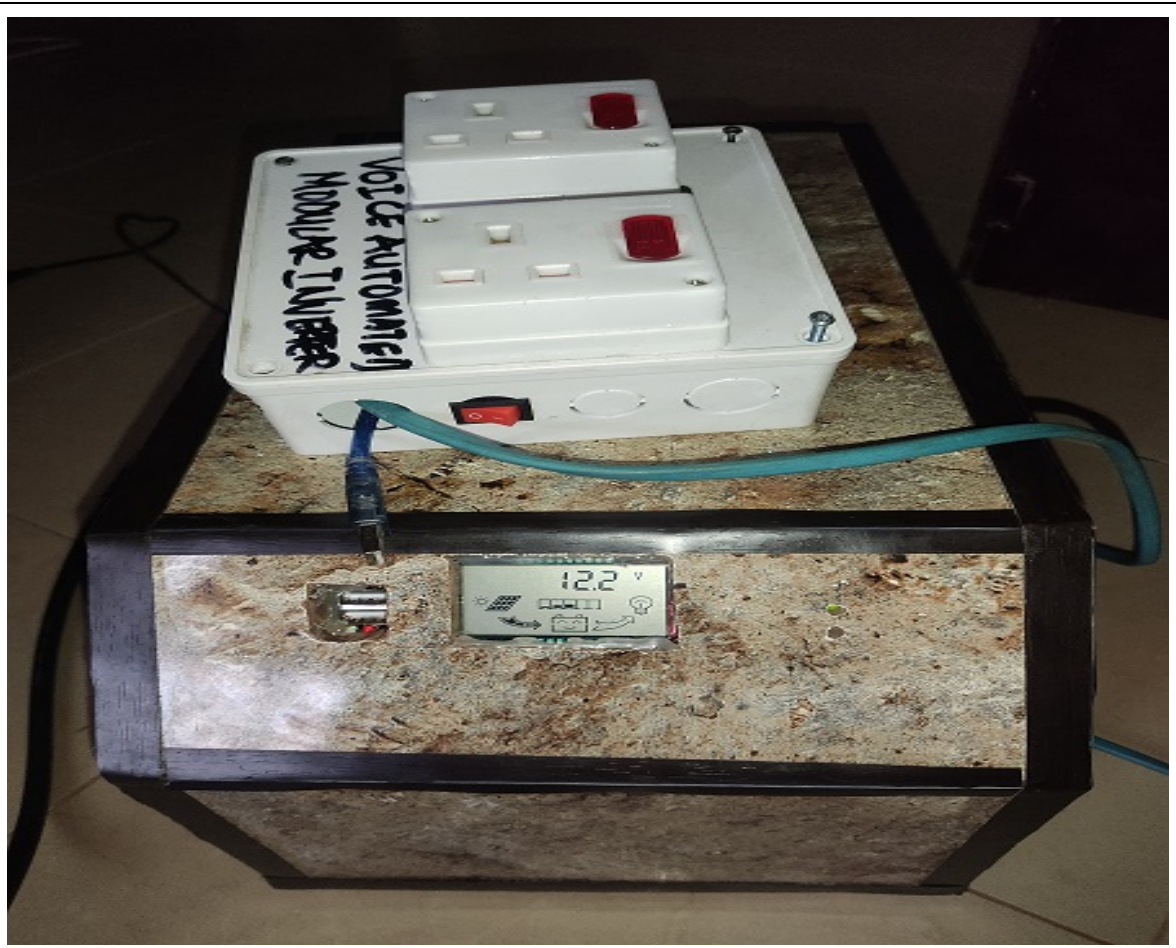

Figure 15. Developed System.

Table 6

Bill of Engineering Materials and Evaluation

\begin{tabular}{clccc}
\hline ITEM & \multicolumn{1}{c}{ DESCRIPTION } & COST (N) & QUANTITY & AMOUNT(N) \\
\hline 1 & 2KVA Transformer less Inverter & 35000 & 1 & 35000 \\
& With Charger & & & \\
2 & 12V/100AH Inverter Battery GLT & 38500 & 1 & 38500 \\
3 & Deep Cycle & 7000 & 1 & 7000 \\
4 & 20AMP PWM Charge Controller & 24500 & 1 & 24500 \\
5 & 2V/150WAH Monocrystalline & 800 & 16 & 12800 \\
6 & Arduino Uno & 4500 & 1 & 4500 \\
7 & Capacitors & 50 & 8 & 400 \\
8 & Resistors & 10 & 12 & 120 \\
9 & LCD & 1500 & 1 & 1500 \\
10 & LED & 10 & 5 & 50 \\
11 & Bluetooth Module & 3000 & 1 & 3000 \\
12 & 2-Channel Relay & 2500 & 1 & 2500 \\
13 & Loudspeaker & 1000 & 1 & 1000 \\
14 & PAM 8403 Amplifier Module & 1000 & 1 & 1000 \\
15 & Sockets & 500 & 2 & 1000 \\
16 & Casing & 1500 & 1 & 1500 \\
17 & 9V Battery & 200 & 1 & 200 \\
18 & I/O Connectors & 500 & 2 & 1000 \\
19 & Wires & 500 & 10 & 5000 \\
& & & & $140,570.00$ \\
\hline
\end{tabular}




\section{Conclusion}

This research successfully presented a modular inverter with optimized energy allocation and smart control systems. It was implemented by integrating a mobile application with functionalities such as powering, remote monitoring, switching and control of the inverter, thereby achieving constant optimization of the power flow of the inverter battery. This was achieved by integrating a mobile application and voice control with a smart socket module which was integrated into a solar inverter system. From the results, the system was able to control the power consumption by varying the amount of the load connected to the system. When the load exceeds the threshold, the system will be notified of excess power consumption which will be preceded by immediate advice to cut off supply. This accounted for over $50 \%$ of power being conserved, thereby saving the battery life from excess load above its threshold. In addition to the fact that solar-powered inverters help reduce environmental pollution, this research further makes the usage of green energy more efficient with its feature which allows for proportionate or equal distribution of energy. It allows for easy remote monitoring through the mobile application and the introduction of the concept of loT. The system also helps prevent energy theft or misuse by providing only the proper user with alerts and administrative control.

\section{Future Directions}

Numerous changes can be made to the current design and technology, as well as numerous new features that can be added:

- Increasing the capacity of the system or adding support for general power distribution of the general power supply to help make it more efficient and less costly for its users.

- The subsequent systems can look into the addition of a GSM module to the system which will allow remote monitoring and control of the device through a short messaging service (SMS) using the AT command (Attention command).

- GPS tracking can also be integrated into the system, allowing the position of the solar inverter module to be determined in the case of theft.

- The mobile application should be embedded with security measures (login) like biometrics login, and key login to ensure that the system is not used by intruders.

\section{Acknowledgements}

The Department of Computer Engineering at the Federal University of Technology in Minna, Niger State, Nigeria, provided support for this research. The authors are grateful to the university administration for providing a suitable research laboratory.

\section{References}

1. Kumar A., Bijapur A. A., Charitha B., Kulkarni K. R., and Natarajan K. An IOT based smart inverter. In: 2016 IEEE International Conference on Recent Trends in Electronics, Information \& Communication Technology (RTEICT), 2016, pp. 1976-1980: IEEE.

2. Joshi M. A. and Kavyashree S. IOT Based Smart Inverter Using Raspberry PI. In: International Journal of Latest Technology in Engineering, Management \& Applied Science, 2017.

3. Osanyinpeju K. L., Aderinlewo A. A., Adetunji O. R. and Ajisegiri E. Performance evaluation of monocrystalline photovoltaic panels in Funaab, Alabata, Ogun State, Nigeria weather condition In: Performance Evaluation, vol. 5, no. 2, pp. 8-20, 2018.

4. G. K. Rathy G A, Karthikeyan Perumal, Sivasankar P. An IoT-Based Controller Realization for PV System Monitoring and Control. In: International Journal of Computer Trends and Technology (IJCTT), vol. 68, no. 4, pp. 151-158, 2020. 
5. Cangi H. and Adak S. Analysis of solar inverter THD according to PWM's carrier frequency. In: 2015 International Conference on Renewable Energy Research and Applications (ICRERA), 2015, pp. 194-198: IEEE.

6. Premkumar M., and Sumithira T. Design and implementation of new topology for solar PV based transformerless forward microinverter. In: Journal of Electrical Engineering \& Technology, vol. 14, no. 1, pp. 145-155, 2019.

7. Janardhan K., Mittal A., and Ojha A. Performance investigation of stand-alone solar photovoltaic system with single phase micro multilevel inverter. In: Energy Reports, vol. 6, pp. 2044-2055, 2020.

8. Krishnan N. and Divya H. Solar Smart Inverter: A Novel Design using Multi level Topology and PulseWidth Modulation with Load Detection. In: International Journal of Engineering Research and, vol. 4, no. 06, 2015.

9. Gupta S., Kekatos V. and Jin M. Deep Learning for Reactive Power Control of Smart Inverters under Communication Constraints. In: 2020 IEEE International Conference on Communications, Control, and Computing Technologies for Smart Grids (SmartGridComm), 2020, pp. 1-6: IEEE.

10. Kannan R. and Subbaraman S. Solar powered Modified Coupled Inductor, Capacitor Multiplier boost converter operated three-phase small power inverter. In: International Journal of Circuit Theory and Applications, vol. 49, no. 3, pp. 683-703, 2021.

11. Hossein Motlagh N., Mohammadrezaei M., Hunt J., and Zakeri B. Internet of Things (IoT) and the energy sector. In: Energies, vol. 13, no. 2, p. 494, 2020.

12. Pilehvar M. S. and Mirafzal B. Smart Inverters for Seamless Reconnection of Isolated Residential Microgrids to Utility Grid. In: 2020 IEEE Electric Power and Energy Conference (EPEC), 2020, pp. 1-6: IEEE.

13. Abbas A. K., Obed A. A., and Abid A. J. Design of a Smart Energy Management System for Photovoltaic StandAlone Building. In: IOP Conference Series: Materials Science and Engineering, 2020, vol. 881, no. 1, p. 012158 : IOP Publishing.

14. Lulbadda K. T. and Hemapala K. The additional functions of smart inverters. In: Aims Energy, vol. 7, no. 6, pp. 971-988, 2019.

15. Adekola O. and Raji A. K.Functionalities of smart inverter system for grid-connected applications. In: 2015 International Conference on the Industrial and Commercial Use of Energy (ICUE), 2015, pp. 340-344: IEEE.

16. Howe J., Oder T., Krausz M., and Güneysu T. Standard lattice-based key encapsulation on embedded devices. In: IACR Transactions on Cryptographic Hardware and Embedded Systems, pp. 372-393, 2018.

17. Hyder F., Baredar P., and Sudhakar K. A novel Sun tracking technique through a Solar PV Tree and a smart controller. In: 2018 4th International Conference on Electrical Energy Systems (ICEES), 2018, pp. 407-411: IEEE.

18. Changsheng Z., Zixuan Z., and Xin H. Design and Implementation of Remote Monitoring System Based on asp. Net. In: 2015 Seventh International Conference on Measuring Technology and Mechatronics Automation, 2015, pp. 354-357: IEEE.

19.Joshi D. S. A., Kolvekar S.,. Raj Y. R and Singh S. IoT based smart energy meter. In: Bonfring International Journal of Research in Communication Engineering, vol. 6, no. Special Issue, pp. 89-91, 2016.

20. Kurundkar S. S. Kamthe, S. More, P. Marathe, and Y. Gadade, Remote monitoring of solar inverter (an application of IOT),Am. J. Eng. Res.(AJER), vol. 6, no. 7, pp. 70-74, 2017.

21. Tajwar A. S. R., Ahmed A., Hazari M. R. and Mannan M. A. Solar Photovoltaic-Based Smart Metering System. In: 2021 2nd International Conference on Robotics, Electrical and Signal Processing Techniques (ICREST), 2021, pp. 530-534: IEEE.

22. Pilakkat D. and Kanthalakshmi S. Single phase PV system operating under Partially Shaded Conditions with ABC-PO as MPPT algorithm for grid connected applications. In: Energy Reports, vol. 6, pp. 1910-1921, 2020.

23. He Y., Wang M.-H., Xu Z. and He Y. Advanced Intelligent Micro Inverter Control in the Distributed Solar Generation System. In: 2019 IEEE 3rd Conference on Energy Internet and Energy System Integration (EI2), 2019, pp. 1922-1927: IEEE. 